\title{
PEMBELAJARAN SECARA KOLABORATIF JURUSAN TKJ PADA MATA PELAJARAN SISTEM KOMPUTER DI SMK NEGERI 2 KOTABUMI
}

\author{
Khusnul Khotimah ${ }^{1}$, M. Fadli ${ }^{2}$ \\ ima.ukhti@gmail.com \\ ${ }^{1}$ Universitas Muhammadiyah Kotabumi \\ ${ }^{2}$ SMK Negeri 2 Kotabumi
}

\begin{abstract}
Collaborative Learning in Sistem Komputer subject is the core of this study. The aim of this research is to find out how the effects of applying Collaborative Learning in Computer System Subject at SMK Negeri 2 Kotabumi class TKJ. The research method used in this study is descriptive qualitative, the implementation of Collaborative Learning is carried out in several aspects, namely: preparing teaching materials, and learning media, as well as the process of implementing learning in class. The Implementation of collaborative learning as many as 8 meetings. The research subjects were students of SMK Negeri 2 Kotabumi Class X TKJ 2. The results of observation during learning can be concluded that Collaborative learning can be an alternative in improving the quality of learning.
\end{abstract}

Keyword: Collaborative Learning, Computer System

\begin{abstract}
Abstrak: Pembelajaran kolaboratif dalam mata pelajaran Sistem Komputer adalah inti dari penelitian ini. Tujuan dari penelitian ini adalah untuk mengetahui bagaimana pengaruh implementasi pembelajaran secara kolaboratif di SMK Negeri 2 Kotabumi kelas TKJ pada mata pelajaran Sistem Komputer. Metode penelitian yang digunakan adalah deskriptif kualitatif. Pelaksanaan Pembelajaran Kolaboratif dilakukan dalam beberapa aspek, yaitu: mendesain bahan ajar dan menyiapkan media pembelajaran, serta proses pelaksanaan pembelajaran di dalam kelas. Implementasi pembelajaran kolaboratif sebanyak 8 pertemuan. Subjek penelitian adalah siswa kelas X TKJ SMK Negeri 2 Kotabumi 2. Hasil pengamatan selama pembelajaran dapat disimpulkan bahwa pembelajaran kolaboratif dapat menjadi alternatif dalam meningkatkan kualitas pembelajaran.
\end{abstract}

Kata Kunci: Pembelajaran kolaborasi, Sistem Komputer

\section{PENDAHULUAN}

Salah satu upaya Pemerintah dalam meningkatkan mutu pendidikan Indonesia terus digalakkan sebagaimana tertuang dalam Peraturan Presiden nomor delapan tahun 2012 mengenai kurikulum Kerangka Kualifikasi Nasional Indonesia yang kemudian disingkat (KKNI) dan dipertegas dalam Undang-undang nomor dua belas tahun 2012 pasal 35 ayat 2 agar bentuk kurikulum yang dikembangkan oleh setiap perguruan tinggi harus dengan dasar standar nasional yang ditetapkan pendidikan tinggi. Sehingga nantinya setiap perguruan tinggi di Indonesia dapat menghasilkan lulusan yang memiliki kemampuan sesuai kualifikasi dan standar kompetensi yang telah dirumuskan.

Kualifikasi dan standar kompetensi yang ditetapkan perguruan tinggi diharapkan sesuai dengan kebutuhan dunia kerja. Pemerintah melalui Kemenristekdikti mengembangkan suatu program revitalisasi yang dikenal dengan program 
penugasan dosen ke sekolah (PDS) oleh Lembaga Pendidikan Tenaga Kependidikan (LPTK). Tujuan dari kegiatan ini agar LPTK selaku penyedia lulusan terdidik dapat menyusun kurikulum yang relevan, inovatif dan kompetitif sesuai kebutuhan dunia kerja. Kolaboratif dilakukan antara dosen dengan guru dalam pembelajaran di sekolah. Bentuk kolaboratif yang dilakukan terdiri dari beberapa aspek, yaitu: persiapan perangkat pembelajaran, desain bahan ajar dan mempersiapkan media pembelajaran yang akan digunakan pada pelaksanaan pembelajaran di dalam kelas.

Pembelajaran secara Kolaborasi merupakan aktivitas yang melibatkan dua orang atau lebih dalam sebuah tim yang secara bersama-sama melakukan aktifitas belajar. Dosen dan guru yang berkolaborasi bekerjasama untuk meningkatkan pengetahuan dan keterampilan dalam pembelajaran terhadap siswa sesuai dengan situasi dan kondisi yang ada. Pembelajaran yang dilakukan juga menekankan pada peningkatan kualitas siswa dalam belajar (student center)

Melalui kegiatan PDS diharapkan memberikan dampak positif baik bagi perguruan tinggi maupun bagi pihak sekolah yang menjadi mitra kegiatan. Sekolah yang dijadikan mitra dalam program PDS ini salah satunya adalah SMK Negeri 2 Kotabumi dengan nilai akreditasi sekolah A. Kolaborasi dilakukan pada mata pelajaran Sistem Komputer di kelas X TKJ 2.

Sistem komputer merupakan salah satu mata pelajaran jurusan TKJ yang wajib dipelajari di SMK. Mata pelajaran ini merupakan dasar bidang keahlian teknologi informasi dan komunikasi. Kegiatan peningkatan kualitas pembelajaran pada mata pelajaran sistem komputer dilakukan dengan melakukan pembelajaran kolaboratif. Pembelajaran kolaboratif meliputi hal berbagi dan bertukar informasi, saling memberi dan mengevaluasi ide, dan saling mengamati pekerjaan dalam satu tim.

Barkley (2014) menyatakan bahwa Collaborative Learning Techniques (teknik pembelajaran kolaboratif) didefinisikan sebagai kegiatan bekerjasama dengan orang lain. Keohane dalam Budi (2013) menyatakan kolaborasi merupakan kerjasama dengan orang lain, bekerja dalam satu team/kelompok, berbaur dalam sebuah team/kelompok untuk keberhasilan bersama. Pendapat lain dikemukakan oleh Patel dalam Budi (2013) bahwa kolaborasi merupakan sebuah proses ketergantungan fungsional dalam mencoba keterampilan koordinasi, to coordinate skills, tools, and rewards. Jadi dapat disimpulkan bahwa pembelajaran kolaborasi merupakan pembelajaran yang dilakukan secara bersamasama dalam suatu tim/kelompok. 
Pembelajaran secara Kolaborasi yang dilakukan di penelitian ini yaitu kolaborasi antara dosen komputer selanjutnya disebut (dosen pelaksana) dan seorang guru komputer SMK Negeri 2 Kotabumi yang selanjutnya disebut (guru mitra). Bentuk Kolaborasi meliputi persiapan perangkat pembelajaran, membuat bahan ajar dan desain media pembelajaran, serta teknis proses pembelajaran di dalam kelas.

Manfaat dari program PDS ini adalah:

1. dapat memperkuat filosofi tentang keilmuan, disiplin ilmu, serta sistem pendidikan guru

2. LPTK sebagai menyelenggarakan pendidikan dapat meningkatkan secara profesional untuk menghasilkan guru serta tenaga kependidikan yang baik dan berkualitas

3. menjadi referensi dan inovasi pembelajaran yang berbasis riset supaya terwujud pembelajaran yang efektif melalui kegiatan pengabdian kepada masyarakat

4. Memperkuat sumber daya manusia, manajemen kelembagaan, serta sumber daya lainnya,

5. meningkatkan daya saing LPTK yang mengacu pada standar mutu pendidikan tinggi

6. meningkatkan profesionalisme lulusan dan kualitas akademik pada tingkat LPTK.

\section{METODE}

Metode dalam penelitian ini adalah deskriptif kualitatif. Menurut Sugiyono (2010) metode deskriptif kualitatif merupakan metode penelitian yang didasarkan pada filsafat positivisme, metode ini digunakan di penelitian dengan kondisi obyek yang alamiah, peneliti sebagai kunci, teknik pengambilan sampel sumber data dilakukan secara purposive dan snowbaal, teknik pengumpulan dilakukan secara trianggulasi, proses analisis data bersifat induktif/kualitatif, dan hasil penelitian secara kualitatif lebih menekankan makna generalisasi.

Pelaksanaan pembelajaran kolaboratif dilaksanakan dalam 8 pertemuan. Siswa yang menjadi subjek penelitian adalah Siswa kelas $\mathrm{X}$ TKJ 2 dengan jumlah 35 orang. Teknik pengumpulan data diperoleh dari hasil pengamatan dan catatan lapangan.

\section{HASIL DAN PEMBAHASAN}

\section{Hasil}

Adapun hasil yang diperoleh selama pengamatan dan pelaksanaan program kolaborasi adalah sebagai berikut.

a. Teknik kolaboratif merupakan upaya efektif dalam peningkatan kualitas pembelajaran terhadap siswa. Dimana terdapat sebuah proses perencanaan pembelajaran, teknik pelaksanaan/ pe- 
ngelolaan pembelajaran di kelas, penggunaan media dan bahan ajar, sampai proses evaluasi saat pembelajaran selesai dilakukan.

b. pembelajaran kolaboratif menekankan pembelajaran yang berpusat pada siswa (studen center) sehingga siswa dapat lebih aktif selama pembelajaran berlangsung.

c. Siswa dapat meningkatkan kualitas cara belajar yang maksimal dan meningkatkan hubungan kerjasama antar siswa dalam kelompok.

\section{Pembahasan}

Pelaksanaan kolaborasi dilakukan dalam beberapa Tahap. Tahap pembelajaran yang dilaksanakan di SMK Negeri 2 Kotabumi pada mata pelajaran Sistem Komputer kelas X TKJ 2 dilaksanakan dalam tiga tahapan yang mencakup plan (merencanakan), Do (melaksanakan), dan See (refleksi) sebagai berikut.

\section{Plan (Merencanakan)}

Tahap merencanakan/perencanaan (Plan), yang pertama saat penyusunan perangkat pembelajaran. Perangkat pembelajaran yang dihasilkan dalam program ini diantaranya silabus mata pelajaran dan rencana proses pembelajaran untuk 4 kompetensi dasar yang sebelumnya telah didiskusikan oleh dosen pelaksana dan guru mitra. Perangkat pembelajaran yang digunakan adalah hasil dari diskusi tim (dosen pelaksana dan guru mitra) tentunya dengan memperhatikan keilmuan dan pengalaman mengajar keduanya dibidang komputer. Beberapa hal yang dilihat pada penyusunan rencana pembelajaran ini diantaranya adalah taraf kesukaran dari materi, teknik, metode, dan strategi pembelajaran yang dapat mendorong siswa lebih aktif, alokasi waktu pelaksanaan pembelajaran yang tersedia, dan pemilihan pemberian tugas yang dapat meningkatkan kemampuan siswa didasarkan pada karakteristik siswa.

Kolaborasi lainnya seperti dalam hal penyusunan materi bahan ajar dan media pembelajaran. Bahan ajar yang disusun disesuaikan dengan kurikulum sekolah dan pemilihan media pembelajaran yang tepat untuk membantu siswa lebih memahami materi yang disampaikan dalam pembelajaran sesuai dengan bahan ajar. Bahan ajar yang disusun meliputi materi sistem bilangan dan gerbang logika.

Penerapan proses pembelajaran di kelas dilaksanakan secara kolaborasi antara dosen pelaksana dan guru mitra. Pada saat dosen pelaksana bertindak sebagai pemateri guru mitra melakukan pengamatan dan penilaian terhadap kegiatan siswa demikian pula sebaliknya. Pelaksaan program ini dilakukan sebanyak 8 kali pertemuan dengan 3 kompetensi dasar. 


\section{Do (Pelaksanaan)}

Secara umum tahap pelaksanaan pembelajaran kolaborasi selama 8 pertemuan terdiri atas: bagian awal/pendahuluan, bagian inti, dan bagian penutup. Perbedaan terletak pada pemberian materi pada setiap pertemuannya. Dengan uraian sebagai berikut.

a. Pada bagian awal/pendahuluan, disusun langkah-langkah pembelajaran yang meliputi: 1) Guru mengawali pembelajaran dengan salam dan berdoa bersama, sebagai penerapan nilai religius, 2) cek absen kehadiran siswa sebagai penerapan sikap disiplin, 3) menyiapkan fisik dan psikis siswa dalam pembelajaran yang akan dilakukan, 4) menyampaikan tujuan materi pembelajaran, 5) mengaitkan materi pembelajaran dengan pengalaman siswa dengan materi sebelumnya, dan 6) guru menjelaskan tatacara sistem penilaian dalam belajar.

b. Pada bagian inti, disusun langkahlangkah pembelajaran yang meliputi: 1) guru memberikan stimulus dari materi yang akan dipelajari dan siswa diberikan bahan bacaan, 2) guru membagi siswa dalam beberapa kelompok yang beranggota antara 3-4 orang. 3) siswa secara berkelompok berdiskusi untuk menyelesaikan permasalahan yang diberikan guru, 4) siswa yang menjadi wakil dari masing-masing kelompok menyajikan hasil tugasnya.

c. Pada bagian penutup, langkah kegiatan pembelajaran meliputi: 1) guru dan siswa bersama-sama menyimpulkan materi yang telah dipelajari, 2) guru memberikan penilaian pengetahuan memalui tes tertulis, 3) mengakhiri pembelajaran dengan berdoa dan salam penutup.

Penerapan pembelajaran kolaborasi antara dosen pelaksana dan guru mitra pada mata pelajaran sistem komputer di SMK Negeri 2 berlangsung selama 8 kali pertemuan dengan 4 kompetensi dasar yang disampaikan kepada siswa secara bersama-sama. Materi yang pertama adalah tentang sistem bilangan, kompetensi dasar yang diajarkan adalah 1) memahami sistem bilangan (desimal, biner, dan heksadesimal), 2) Mengkonversikan sistem bilangan (desimal, biner, dan heksadesimal) dalam memecahkan masalah.

Pertemuan pertama, materi pembahasan dengan indikator: menganalisis sistem bilangan (desimal, biner, dan heksadesimal). Pertemuan kedua, materi pembahasan dengan indikator: menjelaskan sistem bilangan desimal, biner, dan heksadesimal). Pertemuan ketiga, materi pembahasan dengan indikator: mengkonversikan sistem bilangan (desimal, biner, dan heksadesimal) dalam pemecahan masalah konversi. Pertemuan keempat, 
materi pembahasan dengan indikator: mendemonstrasikan sistem bilangan (desimal, biner, dan heksadesimal) dalam pemecahan masalah konversi.

Materi yang kedua adalah tentang gerbang logika, kompetensi dasar yang diajarkan adalah 1) Menganalisis relasi logika dasar, kombinasi dan sekuensial (NOT, AND, OR), (NAND, NOR, EXOR, EXNOR), (Flip-Flop, counter). 2) Merangkai fungsi gerbang logika dasar, kombinasi dan sekuensial (NOT, AND, OR), (NAND, NOR, EXOR, EXNOR) melalui ujicoba (Flip-Flop, counter). Pertemuan pertama, materi pembahasan dengan indikator menganalisis relasi logika dasar, kombinasi dan sekuensial (NOT, AND, OR); (NOR, NAND, EXOR, EXNOR), (Flip-Flop, counter). Pertemuan kedua, materi pembahasan dengan indikator: menjelaskan relasi logika dasar, kombinasi dan sekuensial (NOT, AND, OR); (NAND, NOR, EXOR, EXNOR), (FlipFlop, counter). Pertemuan ketiga, materi pembahasan dengan indikator pembelajaran mengenai merangkai fungsi gerbang logika dasar, kombinasi dan sekuensial (NOT, AND, OR); (NAND, NOR, EXOR, EXNOR), (Flip-Flop, counter). Pertemuan keempat, materi pembahasan dengan indikator: mendemonstrasikan fungsi gerbang logika dasar, kombinasi dan sekuensial (NOT, AND, OR); (NAND, NOR, EXOR, EXNOR), (Flip-Flop, counter).

\section{Refleksi (See)}

Kegiatan refleksi dilakukan setelah kegiatan pembelajaran (do) selesai dilaksanakan, dosen pelaksana bersama guru mitra melakukan diskusi berdasarkan temuan hasil pengamatan yang terjadi selama pembelajaran berlangsung. Sebagai contoh pada catatan hasil refleksi pada kegiatan pertama menunjukkan beberapa aktifitas yang belum cukup baik. Siswa terlihat masih sangat kaku dalam pembelajaran. Hal ini mungkin dikarenakan siswa belum terbiasa dengan adanya 2 orang guru di dalam kelas. Ketika dikelompokkan, siswa masih belum aktif terlibat diskusi menyelesaikan lembar tugas yang diberikan. Pembelajaran secara Kolaborasi tim antara dosen pelaksana dan guru mitra pun dalam belum terlalu baik. Penyampaian materi pada pembelajaran awal masih didominasi guru mitra. Berdasarkan hasil temuan tersebut, dosen pelaksana bersama guru mitra merencanakan upaya perbaikan pembelajaran pada pertemuan berikutnya untuk peningkatan kinerja dan perbaikan mutu pembelajaran yang dilaksanakan di sekolah.

\section{SIMPULAN}

Simpulan berdasarkan hasil observasi/ pengamatan lembar jurnal refleksi yang diisi oleh dosen pelaksana dan guru mitra selama proses kolaborasi bahwa penerapan 
pembelajaran kolaboratif pada mata mengembangkan kurikulum yang lebih pelajaran Sistem Komputer di SMK Negeri relevan di perguruan tinggi sebagai LPTK. 2 Kotabumi dapat membantu dosen Simpulan akhir pelaksanaan pembelajaran pelaksana dan guru mitra untuk saling secara kolaboratif mata pelajaran sistem belajar. Hasil pengamatan dan pengalaman komputer di SMK Negeri 2 Kotabumi melalui program PDS akan dijadikan bahan efektif memberikan peningkatan kualitas evaluasi dan sekaligus sebagai data untuk pembelajaran antara dosen, guru, dan siswa.

\section{DAFTAR RUJUKAN}

Elizabert E. Barkley, K. Patricia Cross, Clarie Howell Major. (2014). Collaborative Learning Techniques. Bandung: Nusa Media.

Rusman. (2010). Model-Model Pemebelajaran Mengembangkan Profesionalisme Guru. Bandung: Raja Grafindo Persada.

Sugiyono. (2010). Metode Penelitian Kuantitatif Kualitatif dan R\&D. Bandung: Alfabeta.

Yalinda, Yonita Yulia. Noviana. (2018). Sistem Komputer. Solo: Mediatama

https://kurniawanbudi04.wordpress.com/2013/05/27/collaborative-learning/ 